\section{ADMINITRASI KEUANGAN}

\author{
Nola nopita \\ Universitas Negeri Padang \\ Indonesia \\ E-mail : \\ nollanopita@gmail.com
}

\begin{abstract}
Abstrak-
Definition of finnancinal nadministrnation in the bronadest sense is na policy regnarding the nand use of orgnaniznationnal finnance to renalize the nactivities of the orgnaniznation, where the form of finnancinal mnannagement includes plnanning, regulnation, naccountnability, nand finnancinal supervision
\end{abstract}

I.PENDAHULUAN Administrasi Keuangan adalah upaya pengelolaan mencakupsemua aktivitas yang berhubungan erat dengan semua system keuangan untuk mencapai tujuan tiap perusahaanatau organisasi.

Menurut para ahli pengertian administrasi dibagi menjadi 2 yaitu : I. Arti sempit Administrasi keuangan dalam arti sempit yaitu segala pencatatan masuk dan keluarnya keuangan

untuk membiayai suatu kegiatan organisasi kerja yang berupa tata usaha atau tata pembukuan keuangan.

\section{Arti Luas}

Administrasi keuangan menurut arti luas yaitu kebijakan dalam pengadaan dan penggunaan keuangan untuk mewujudkan kegiatan organisasi kerja yang berupa kegiatan perencanaan, pengaturan pertanggungjawaban, dan pengawasan keuangan.

Menurut Ubben, Hughes \& Norris (dalam Nurhizrah Gistituati, 2012: 150) kegiatan menajemen keuangan sekolah cukup variatif, mulai dari yang sangat sederhana, yaitu perencanaan keuangan yang sangat sederhana, sampai pada pengelolaan keungangan yang sangat kompleks, akibat dari perencanaan kegiatan yang kompleks.

Menurut Depdiknas (2000) bahwa manajemen keuangan merupakan tindakan pengurusan/ketatausahaan keuangan yang meliputi pencatatan, perencanaan,

pelaksanaan, pertanggungjawaban dan pelaporan Dengan demikian, manajemen keuangan sekolah dapat diartikan sebagai rangkaian aktivitas mengatur keuangan sekolah mulai dari perencanaan, pembukuan, pembelanjaan, pengawasan dan pertanggung-jawaban keuangan sekolah. Pembiayaan pendidikan hendaknya dilakukan secara efisien.

Makin efisien suatu sistem pendidikan, semakin kecil dana yang diperlukan untuk pencapaian tujuan-tujuan pendidikan. Untuk itu, bila sistem keuangan sekolah dikelola secara baik akan meningkatkan efisiensi penyelenggaraan pendidikan. Artinya, dengan anggaran yang tersedia, dapat mencapai tujuan-tujuan pendidikan secara produktif, efektif, efisien, dan relevan antara kebutuhan di bidang pendidikan dengan pembangunan masyarakat.(Afriansyah, 2019)

Untuk mencapai hal-hal seperti di atas maka diperlukan adanya proses merencanakan, mengorganisasikan, mengarahkan, mengkoordinasikan, mengawasi, dan melaporkan kegiatan bidang keuangan agar tujuan sekolah dapat tercapai secara efektif dan efisien.

Melalui kegiatan manajemen keuangan maka kebutuhan pendanaan kegiatan sekolah dapat direncanakan, diupayakan pengadaannya, dibukukan secara

transparan, dan digunakan untuk membiayai pelaksanaan program sekolah secara efektif 
dan efisien. Untuk itu tujuan manajemen keuangan adalah:

a. Meningkatkan efektivitas dan efisiensi penggunaan keuangan sekolah

b. Meningkatkan akuntabilitas dan transparansi keuangan sekolah.

c. Meminimalkan penyalahgunaan anggaran sekolah.

Untuk mencapai tujuan tersebut, maka dibutuhkan kreativitas kepala sekolah dalam menggali sumber-sumber dana, menempatkan bendaharawan yang menguasai dalam pembukuan dan pertanggung-jawaban keuangan serta memanfaatkannya secara benar sesuai peraturan perundangan yang berlaku.

Dalam menajeman keuangan sekolah terdapat rangkaian kegiatan yang dimulai dengan perencanaan, yaitu merencanakan program kegiatan dan memperkirakan, serta menetapkan anggaran pendapatan keuangan sekolah, penggunaan anggaran sokolah sesuai dengan perencanaan sekolah, pengawasan atau pengendalian penggunaan keuangan sekolah, dan pertanggungjawaban penggunaan, serta pelaporannya. Sebagaimana yang dikemukakan oleh Depdiknas (2002),

menajemen keuangan adalah tindakan pengurusan atau ketatausahaan keuangan yang meliputi perencanaan, pelaksanaan dan pencatatan, pertanggungjawaban dan pelaporan keuangan.Dengan demikian, menajemen keuangan sekolah merupakan rangkaian aktivitas mengatur keuangan sekolah mulai dari perencanaan, pembukuan, pembelajaran, pengawasan, pertanggungjawaban dan pelaporan keuangan sekolah. a. Tujuan Menajemen Keungan Sekolah

1. Meningkatkan efektifitas dan efisiensi penggunaan keuangan sekolah.

2. Meningkatkan akuntabilitas dan transparansi keuangan sekolah.

3. Meminimalkan penyalahgunaan anggaran sekolah.

b. Prinsip-prinsip keuangan sekolah

1. Prinsp transparan

Mengandung makna bahwa dalam pengelolaan keuangan sekolah harus ada keterbukaan, dalam artian memberikan informasi yang jelas kepada pihak-pihak yang berkepentingan tantang dari mana sumber data diperoleh, berapa jumlahnya, untuk apa dana itu digunakan dan bagaimana rincian penggunaannya, serta pertanggungjawabannya.

\section{Prinsip efisiensi}

Penggunaan sumber daya keuangan yang ada harus betul-betul tapat guna, yaitu sesuai antara yang dikeluarkan dengan yang dihasilkan. Dengan kata lain penggunaan sumber daya keuangan sekolah harus bujak dan hemat. Efisiensi biasanya diukur dengan membandingkan antara masukan atau yang digunakan dengan yang dikeluarkan atau yang dihasilkan

\section{Prinsip Akuntabilitas}

Setiap sumber daya keuangan sekolah yang digunakan harus di pertanggungjawabkan baik secara administratif maupun secara normative. Pertanggungjawaban administrasi disini maksudnya adalah penggunaan keuangan sekolah jelas pembukuannya, ada buktibukti penggunaannya, serta hasilnya 
1. Proses Administrasi Keuangan (Penyusunan RPS, RKAS, Penggunaan, dan Pertanggungjawaban)

Penyusunan RPS

Rencana Pengembangan Sekolah (RPS) merupakan salah satu wujud dari salah satu fungsi manajemen sekolah yang amat penting, yang harus dimiliki sekolah untuk dijadikan sebagai panduan dalam

menyelenggarakan pendidikan di sekolah, baik untuk jangka panjang (20 tahun), menengah (5 tahun) maupun pendek (satu tahun).

Atas dasar itu, Depdiknas telah menyiapkan sebuah panduan teknis bagi sekolah dalam penyusunan Rencana Pengembangan Sekolah, yang disampaikan oleh Prof. Slamet PH. MA, MEd, MA, MLHR, Ph.D, yang mengupas tentang:

1).Pentingnya Rencana Pengembangan Sekolah (RPS).

RPS penting dimiliki untuk memberi arah dan bimbingan para pelaku sekolah dalam rangka menuju perubahan atau tujuan sekolah yang lebih baik (peningkatan, pengembangan) dengan resiko yang kecil dan untuk mengurangi ketidakpastian masa depan.

\section{2). Arti Perencanaan Sekolah/RPS.}

Perencanaan sekolah adalah suatu proses untuk menentukan tindakan masa depan sekolah yang tepat, melalui urutan pilihan, dengan memperhitungkan sumberdaya yang tersedia.RPS adalah dokumen tentang gambaran kegiatan sekolah di masa depan dalam rangka untuk mencapai perubahan/tujuan sekolah yang telah ditetapkan.
3). Tujuan Rencana Pengembangan Sekolah (RPS).

RPS disusun dengan tujuan untuk: (1) menjamin agar perubahan/tujuan sekolah yang telah ditetapkan dapat dicapai dengan tingkat kepastian yang tinggi dan resiko yang kecil; (2) mendukung koordinasi antar pelaku sekolah; (3) menjamin terciptanya integrasi, sinkronisasi, dan sinergi baik antar pelaku sekolah, antarsekolah dan dinas pendidikan kabupaten/kota, dan antarwaktu

4). Sistem Perencanaan Sekolah (SPS).

Sistem Perencanaan Sekolah adalah satu kesatuan tata cara perencanaan sekolah untuk meng-hasilkan rencana-rencana sekolah (RPS) dalam jangka panjang, jangka menengah, dan tahunan yang dilaksanakan oleh unsur penyelenggara sekolah dan masyarakat (diwakili oleh komite sekolah).

5). Tahap-tahap Penyusunan Rencana Pengembangan Sekolah (RPS),

RPS mencakup:

a) Melakukan analisis lingkungan strategis sekolah;

b) Melakukan analisis situasi untuk mengetahui status situasi pendidikan sekolah saat ini (IPS);

c) Memformulasikan pendidikan yang diharapkan di masa mendatang;

d) Mencari kesenjangan antara butir $2 \& 3$;

e) Menyusun rencana strategis;

f) Menyusun rencana tahunan;

g) Melaksanakan rencana tahunan; dan

h) Memonitor dan mengevaluasi.

Penyusunan RKAS 
Tujuan penyusunan RKAS

1) Memberikan arah yang jelas terhadap program sekolah

2) Merencanakan kegiatan-kegiatan sekolah di masa yang akan datang

3) Menjamin tercapainya integrasi, sinkronisasi, dan sinergi pendanaan pada kegiatan-kegiatan sekolah.

4) Menjamin keterkaitan dan konsistensi antara perencanaan penganggaran, pelaksanaan dan pengawasan.

5) Mengoptimalakan partisipasi warga sekolah dan masyarakat dan hal dukungan dan pengawasan.

6) Mengoptimalkan partisipasi warga sekolah dan masyarakat beserta hal dukungan financial.

7) Menjamin tercapainya penggunaan sumber dana secara efisien, efektif, berkeadilan, dan berkesinambungan.

c. Pertanggungjawaban Keuangan Sekolah

Tanggung jawab yang paling penting dari menajer sekolah terhadap pemerintah, dan juga terhadap komite sekolah, masyarakat, serta guru-guru adalah laporan mengenai kondisi keungan sekolah (Rebore \& Rebore dalam Narhizrah,2013:185). Penerimaan dan pengeluaran keuangan sekolah harus dilaporkan dan dipertanggungjawabkan secara rutin oleh manajer sekolah sesuai dengan peraturan yang berlaku. Pelaporan dan pertanggungjawaban anggaran yang berasal dari orang tua peserta didik dan masyarakat dilakukan secara rinci dan transparan sesuai dengan sumber dana. Pelaporan dan pertanggungjawaban anggaran yang berasal dari usaha mandiri sekolah dilakukan lainnya. Laporan pertanggungjawaban keungan ini penting, agar pemerintah atau masyarakat pemberi dana tahu untuk apa saja uang yang telah diberikan ke sekolah dimanfaatkan, apakah kegiatan yang didukung oleh dana tersebut terlaksana atau terimplementasikan

sebagaimana yang direncanakan, serta bagaimana hasil kegiatan yang didukung oleh dana tersebut, dan bagaimana dampaknya terhadap pelaksanaan tugas utama sekolah, yaitu pembelajaran peserta didik.

\section{METODE PENELITIAN}

Metode Penelitian Artikel ilmiah hendaknya disusundengan metode dan langkah-langkah yang sistematis untuk memudahkan melakukan penelitian. Pada artikel ini, peneliti menggukan mengumpulkan berbagai bahan-bahan atau beberapa materi yang bersumber dari buku, jurnal, internet dan berbagai sumber lainnya. Menurut Zechmester (2000) penelitian kuantitatif menggambarkan suatu pendekatan umum untuk penelitian yang berfokus pada penaksiran pada kovariasi diantara variabel yang muncul secara alami. Penelitian kuantitatif juga kadang-kadang diperlukan sebagai penelitian deskriptif, karena mendeskripsikan kondisi yang telah ada. Penelitian ini melibatkan pengumpulan data untuk menentukan apakah, dan untuk tingkatan apa, terdapat hubungan antara dua atau lebih variabel yang dikuantitatifkan. Penelitian deskriptif adalah penelitian yang digunakan untuk menganalisa data dengan cara mendeskripsikan atau menggambarkan

data yang telah terkumpul sebagaimana adanya tanpa bermaksud membuat kesimpulan yang berlaku umum atau generalisasi. 